\title{
Theatrical Exchanges across the Baltic Sea in the 1930s
}

\section{HANNA KORSBERG}

\begin{abstract}
This article explores theatrical exchanges across the Baltic Sea in the 1930s as part of the cultural diplomacy of recently independent Finland. The Finnish National Theatre visited the Estonia Theatre in Tallinn in 1931 and in 1937, and the Royal Dramatic Theatre in Stockholm in 1936. These theatre visits were different in terms of the visiting production. In Stockholm in 1936, and in Tallinn in 1937, the Finnish National Theatre showcased its work, while during the bilateral exchange with the Estonia Theatre in 1931, the main actors of two of the productions visited the other theatre and the audiences saw two hybrid performances of the two productions. Therefore, the visits are discussed in terms of international and transnational exchange.
\end{abstract}

\section{KEYWORDS}

Theatre visits, cultural diplomacy, international, transnational, cultural exchange. 


\section{Theatrical Exchanges across the Baltic Sea in the 1930s}

As part of establishing the international and transnational connections of Finland, the Finnish National Theatre actively sought out possibilities for visits and co-operation in the 1930s. At first, the theatre visited neighbouring countries, the Estonia Theatre in Tallinn in 1931 and 1937, and the Royal Dramatic Theatre in Stockholm in 1936. In this article, I will look at these visits as part of a theatrical exchange of both an international and a transnational nature as well as part of the cultural diplomacy of Finland.

According to Janelle Reinelt, the concept international "signifies more than one nation, and implies cooperation or at the least negotiation between and among multiple entities called nations." ${ }^{1}$ The visits I will be looking at were strongly supported by the state as part of the cultural diplomacy and international activity of the recently independent Finland. The visits discussed in this article could also be described as transnational, as Steven Vertovec defines the concept, since there were multiple ties and interactions between the theatres and individual artists across the borders of nation-states. ${ }^{2}$

However, I will look at the visits as part of cultural diplomacy and international activity focussing on the visiting performances. Therefore, I would argue that the visits were different in terms of their international and transnational nature. In the 1936 and 1937 visits between the Finnish National Theatre, the Royal Dramatic Theatre, and the Estonia Theatre, the overseas location of performing was highlighted and the two theatres showcased their work abroad. During these visits, the interaction between the artists and theatres did not take place on stage, but during other activities which were part of the visit. The performances were international visits of the visiting theatre while the other theatre was merely hosting them. By contrast the 1931 visits between the Estonia Theatre and the Finnish National Theatre were transnational as the two theatres formed hybrid bilingual performances with elements of the two productions of the two theatres.

According to Joseph S. Nye, the resources of culture, value, and politics

1 Reinelt 2008, 4.

2 Vertovec 1999. 
are the basis of a country's soft power. "In international politics, the resources that produce soft power arise in large part from the values an organization or country expresses in its culture, in the examples it sets by its internal practices and policies, and how it handles relations with others. (...) Public diplomacy tries to attract by drawing attention to these potential resources through broadcasting, subsidizing cultural exports, arranging exchanges, and so forth." 4

Nye acknowledges the division of culture into high culture and popular culture. High culture, according to him, is literature, art and, education while popular culture focuses on mass entertainment. ${ }^{5}$ Compared to this division, the theatre visits the Finnish National Theatre undertook in the 1930s represented both high culture and popular culture. The visiting performances in Stockholm represented the high culture whereas the visiting performances in Tallinn represented popular culture. In Stockholm, the Finnish National Theatre visited with three one act plays by Aleksis Kivi, Lea, Night and Day, and Engagement (Lea, Yö ja päivä and Kihlaus), as well as Tartuffe by Molière. In Tallinn, the theatre performed Scapegoat (Syntipukki) by Agapetus, a pen name of Yrjö Soini, Journey's End by R. C. Sherriff, and Unruly Generation (Kuriton sukupolvi) by Mika Waltari. The visiting productions in Stockholm represented the traditional repertoire of the Finnish National Theatre, national and international classics, while the visiting productions in Tallinn were mainly contemporary Finnish comedies. One can argue that they belonged to the traditional repertoire of the theatre as well since one of the tasks of the theatre was, and still is, to support playwriting in the Finnish language.

As Joanne Tompkins has noted, theatre's geographies incorporate not only architectural but also narrative and more abstract interpretations of spatiality, and theatre's connection to a historical, social, and cultural context. ${ }^{6} \mathrm{I}$ am proposing that in addition to this, geographies of theatre do incorporate theatre's artistic and political contexts. In the visits of the Finnish National Theatre in the 1930s is not only a question of the genre of the play produced in a particular place in a certain historical moment but also a question of showcasing the artistic work of a theatre and creating a brand for an art institution abroad. One of the questions is why the theatre chose these particular performances as visiting performances? S. E. Wilmer has argued that "The theatre can serve as a microcosm of the national community, passing judgement on images of itself." In these cases, the Finnish National Theatre wanted to create different images of itself depending on the place they were visiting. In Stockholm, it wanted to be considered as a theatre performing classics, while in Tallinn, the repertoire consisted of modern plays. The Finnish National Theatre was mirroring the repertoire of the visits of the Estonia Theatre Drama Studio. With the visits to the Royal Dramatic Theatre,

\footnotetext{
Nye 2008, 94-109.

4 Nye 2008, 95.

5 Nye 2008, 96.

6 Tompkins 2003, 537-541.

7 Wilmer 2001, 16.
} 
the Finnish National Theatre wanted to strengthen its profile as a theatre performing both Finnish and international classics. All these visits took place with the political and financial support of the Finnish Government. They were part of the cultural diplomacy of the country.

\section{Theatre visits between Helsinki and Tallinn in 1931}

The theatre visits of the Finnish National Theatre started with visits of individual theatre artists, mainly actors. Ants Lauter had visited Helsinki in Artturi Järviluoma's Ostrobotnians (Pohjalaisia) already in 1924, Liina Reiman had visited as Sappho at the Finnish National Theatre in 1928, and Teuvo Puro had visited the Estonia Theatre as Esko in Aleksis Kivi's Heath Cobblers (Nummisuutarit) in $1929 . .^{8}$ In these visits, it was only the main actor who visited the other theatre and therefore the hybrid performances were bilingual and transnational versions of the productions. In the main role, the actor brought elements of the original production.

More frequent visits between Estonia and Finland were encouraged by the "kindred people's movement", supported by the governments of the two countries. The earliest suggestion of simultaneous visits of the ensembles was made by Yrjö Soini in Aitta journal on 1 January 1930. He had seen Topaze by Marcel Pagnol, performed as A-b-c Book of Life (Elu aabits), at the Estonia Theatre in November 1929. According to Soini, the Finnish National Theatre was rehearsing the play. In his opinion, exchanging actors would be a low-cost, concrete means of cooperation and "building the Soomi Bridge in practice, not just in solemn speeches." 9

In his letter to Eino Kalima, Ants Lauter suggested that the Estonia Theatre and the Finnish National Theatre should synchronise their repertoires to enable visits of individual theatre artists. He suggested a few Estonian plays, among them The Blessing of a Crazed Mind (Põrunud aru õnnistus) by Hugo Raudsepp (1931). ${ }^{10}$ It premiered as Siunattu kaistapäisyys at the Finnish National Theatre on 13 January 1932. ${ }^{11}$

The board of the Finnish National Theatre suggested Pagnol's play Topaze (1928). A crucial question was the matter of finance. The board required that the Finnish government pay all the costs of the three to four actors (traveling costs and per diem) who would visit Estonia. The actors of the production were also mentioned in the minutes of the meeting, Helmi Lindelöf, Mary Hannikainen, Aarne Leppänen, Yrjö Tuominen, Aku Korhonen, Uuno Montonen and Jaakko Korhonen. ${ }^{12}$

Topaze was planned as a visiting program but had to be abandoned only days before the guest performances. The reason for this was the practical difficulties, since the dramatizations of the two productions were so different

8 Veski 2014, 30-33; s.n. Helsingin Sanomat 1.3.1931.

9 Soini Aitta 1.1.1930.

10 A letter from Ants Lauter to Eino Kalima 1.6.1931. The archive of Eino Kalima 533:51:1. Literary and cultural history resources of the Finnish Literature Society.

11 Ilona.

12 The minutes of the Finnish National Board meeting 13.1.1931. Archive of the Finnish National Theatre Archive. 
that a longer rehearsing time would have been necessary for an agreed visit. In the midst of the season, it was not possible. The Topaze visit was planned for May 1931, but eventually did not happen. ${ }^{13}$

\section{Scapegoat and Journey's End in March 1931}

R. C. Sherriff's Journey's End had its world premiere in London in December 1928 with Laurence Olivier, a 21-year-old actor at the time, playing the role of Stanhope. The premiere at the Finnish National Theatre was on 15 November 1929 and the production was performed 47 times. ${ }^{14}$ Journey's End was premiered at the Estonia Theatre in March 1930 as Teekonna Iõpp. ${ }^{15}$ The Finnish National Theatre performed Scapegoat (Syntipukki) by Agapetus on 29 April 1930. In the ensemble were the best actors of the theatre, Aarne Leppänen, Uuno Montonen, Mary Hannikainen, Tyyne Juntto, Päiviö Horsma, Yrjö Tuominen and Joel Rinne. Scapegoat was performed at the Estonia Theatre in December 1930 with the title Patuoinas. ${ }^{16}$

On 3-4 March 1931, a group of actors of the Estonia Theatre visited the Finnish National Theatre. Although it was a visit of individual theatre artists rather than an ensemble, it was advertised as a guest performance between the Estonia Theatre in Tallinn and the Finnish National Theatre in Helsinki. ${ }^{17}$

I would argue that these simultaneous performances were transnational since the bilingual performance was a hybrid performance of the two productions, the Finnish one and the Estonian one. The main parts in Scapegoat were performed by Estonian actors, Albert Üksip (Vaara), Marta Parikas-Niilus (Irja Salo), Hugo Laur (Koikkalainen) and Paul Pinna (Miettinen). At the same time Scapegoat was also performed at the Estonia Theatre with Finnish actors Yrjö Tuominen, Mary Hannikainen, Aarne Leppänen and Uuno Montonen in the respective roles. ${ }^{18}$

The newspapers Helsingin Sanomat, Suomen Sosialidemokraatti, and Uusi Suomi published extensive articles introducing the Estonian visitors. The Uusi Suomi article stated that Minister Aarne Wuorimaa, the Finnish Minister to Tallinn, had supported the negotiations and that cultural exchanges had also taken place in other fields of the arts. ${ }^{19}$ In Helsinki, the performances of Scapegoat and Journey's End were not sold out. However, in the audience at the performance of Scapegoat were President Svinhufvud with his spouse - one of the first official appearances of President Svinhufvud -, Minister of Foreign Affairs Hjalmar Procopé, Minister Aleksander Hellat, and Secretary of the Estonian Embassy, Aleksander Pallo. The board of the Finnish National Theatre also attended the performance. The Minister of Education Paavo Virkkunen attended the performance of Journey's End. ${ }^{20}$

13 s.n. Uusi Suomi 1.3.1931.

14 Koskimies 1972, 857.

15 Tormis 1978, 414.

16 Tormis 1978, 414.

17 The program of Journey's End. Archive of the Finnish National Theatre.

18 s.n. Helsingin Sanomat 2.3.1931.

19 s.n. Helsingin Sanomat 1.3.1931; s.n. Uusi Suomi 1.3.1931.

20 President P. E. Svinhufvud took office on 2 March 1931. Viljanen Helsingin Sanomat 5.3.1931. 
The roles of Hugo Laur and Paul Pinna were considered toned and even tragicomic. ${ }^{21}$ The reception particularly praised the nuanced farce style of Marta Parikas-Niilus and Paul Pinna. The critic of the Suomen Sosialidemokraatti stated that the performances had brought more of a farce style to the Finnish National Theatre ensemble, but still considered it to be shy compared to the bolder and more farcical interpretation of Estonians. ${ }^{22}$

While the reception wished more visits of the entire ensemble to avoid the use of two languages, critics paid more attention to the differences in the style of acting rather than to the language. The Estonian visitors used their mother tongue in the performances, the Finnish actors used their own language. ${ }^{23}$ According to Olavi Paavolainen, watching the bilingual performance of Agapetus's farce had been almost effortless, but watching Journey's End had been challenging, the performance was based on dialogue and Estonian actors were playing the key roles. ${ }^{24}$

However, the critics considered Journey's End a better example of the Estonian acting style. ${ }^{25}$ Ants Lauter starred as Stanhope, and other roles included Albert Üksip (Osborne), Felix Moor (Raleigh), Sergius Lipp (Trotter). Interpretation of Stanhope by Ants Lauter, who was best known in advance by the Finnish public - and critics in particular - received very positive reviews. According to the critics, the acting style of the Estonian actors was different from the Finnish actors. ${ }^{26}$ The interpretation of the National Theatre, directed by Pekka Alpo, was described as highly expressive. The difference in style revealed the weaknesses of the play itself, the superficiality of human portrayal and its "dilettante character as a literary product." 27 The more powerful acting of Alpo's interpretation had covered the weaknesses of the text.

After the performance of Scapegoat, the board of the Finnish National Theatre organised a reception at the Hotel Helsinki. ${ }^{28}$ On the last night, playwright Agapetus, i.e. Yrjö Soini, who was the publisher of Otava and chairman of the Finnish Journalists Association, organised a party in honour of the visitors. The reporter of Uusi Suomi, pseudonym K, wrote that the ice only broke between the Finnish and Estonian actors at that time. The language of communication was a mixture of Finnish and Estonian, but if needed, German was used as an auxiliary language. ${ }^{29}$

In Tallinn, the performances of Scapegoat and Journey's End were sold out. The theatre auditorium was decorated with Finnish and Estonian flags. The audience included, among others, the Speaker of the Estonian Parliament and Head of State Konstantin Päts, as well as members of the Government and

21 Tormis 1978, 218-219.

22 s.n. Suomen Sosialidemokraatti 4.3.1931; M-o Ylioppilaslehti 7.3.1931.

23 Jalkanen Uusi Suomi 7.3.1931; Viljanen Helsingin Sanomat 5.3.1931; s.n. Suomen Sosialidemokraatti 4.3.1931; V. Suomen Sosialidemokraatti 5.3.1931.

24 Paavolainen Aamu 3-4, 1.3.1931.

25 Viljanen Helsingin Sanomat 5.3.1931.

26 s.n. Uusi Suomi 5.3.1931.

27 Jalkanen Uusi Suomi 7.3.1931.

28 s.n. Helsingin Sanomat 4.3.1931.

29 K Uusi Suomi 7.3.1931. The information about Yrjö Soini in Vesikansa. 
Parliament. After the performance of Scapegoat, the Estonia Theatre hosted a dinner party. ${ }^{30}$

The Estonian newspapers published reviews of the visit and the Finnish newspapers reported on the media coverage. The Estonian Scapegoat (Patuoinas) was directed by Harri Paris. ${ }^{31}$ The Finnish visitors were Yrjö Tuominen (Vaara), Mary Hannikainen (Irja Salo), Aarne Leppänen (Koikkalainen), and Uuno Montonen (Miettinen). ${ }^{32}$ In particular, Estonian critics praised Mary Hannikainen and Aarne Leppänen. The magazine Tuulispää's pseudonym Esa Esirippu described Aarne Leppänen as having shined "like a meteor" in Estonia. ${ }^{33}$ The critic of Vaba Maa pointed out that Hannikainen's and Leppänen's interpretations were completely different from those of Estonian actors. Hannikainen's acting in particular had aroused his delight. Journey's End was performed to a full audience and the reception was excellent. ${ }^{34}$ Author A. Adson wrote about the performance in Vaba Maa. According to him, Aarne Leppänen's Stanhope was unforgettable, portraying the humanity of the role. Urho Somersalmi and Yrjö Tuominen were also praised. ${ }^{35}$ The Finnish state also practiced cultural diplomacy in Tallinn, and the Finnish Minister to Tallinn Aarne Wuorimaa, who appreciated theatre, organised a ballroom at the Legation of Finland in honour of the actors. ${ }^{36}$

The pseudonym Köpi criticised the artist visits from the perspective of the economic recession. He claimed that international artists raise so large sums on short tours that they could "save an entire theatre from a shipwreck." He also questioned the highlighting of cultural influences in stark terms, arguing for a period of deprivation, citing a kind of protective duty on the arts. As an acceptable exception to this, he considered the performances of Finns who had worked abroad for a long time, and a few other visits, including a visit to the Royal Swedish Opera and a visit to the Estonia Theatre. According to Köpi, such visits were required by our "international friendships". ${ }^{37}$ According to Suomen Kuvalehti, these visits were "absolutely based on the exceptional cultural sympathy and kinship between Finland and Estonia". ${ }^{38}$

\section{Overseas Performances in 1936 and 1937}

Compared to the visits discussed above, the visits between the Finnish National Theatre and the Royal Dramatic Theatre in 1936, and the Finnish National Theatre's visit to the Estonia Theatre in 1937 were overseas performances where the two visiting theatres showcased their work. These visits were again supported by the states and part of the cultural diplomacy of the countries.

The negotiations between the Finnish National Theatre and the Royal

30 s.n. Uusi Suomi 4.3.1931.

31 Tormis 1978, 414.

32 The program of Patuoinas Estonia Teater. The Archive of Eesti Teatri- ja Muusikamuuseum.

33 Esirippu Tuulispää 15.3.1931.

34 s.n. Helsingin Sanomat 5.3.1931.

35 K Uusi Suomi 6.3.1931.

36 s.n. Helsingin Sanomat 5.3.1931.

37 Köpi Ajan Sana 26.2.1931.

38 Raud Suomen Kuvalehti 28.2.1931. 
Dramatic Theatre began in $1936 .{ }^{39}$ P. K. Tarjanne, Secretary of the Finnish Legation in Stockholm, had contacted the director of the Royal Dramatic Theatre, Olof Molander. Tarjanne suggested that the Finnish National Theatre could visit Stockholm during the Finnish Fair in Stockholm 17-27 April 1936. At the same time, the Royal Dramatic Theatre would visit Helsinki. ${ }^{40}$ The timing of Tarjanne's contact can be connected to the Nordic orientation which was, together with the policy of neutrality, the main objective of the Finnish Government since December 1935. ${ }^{41}$ The visit of the Finnish National Theatre to the Estonia Theatre was part of the celebrations of the Finnish-Estonian relationships in 1937. The Theatre Journals of the two countries published a special issue together. All of these visits included acts of cultural diplomacy. Many high-level politicians were in the audience and the national anthems were played before the performances. Also, the Finnish Embassies in Stockholm and Tallinn held dinner parties or balls in honour of the guests.

In these overseas performances, an interesting question is what the theatres chose as visiting productions. In Stockholm, the Finnish National Theatre chose to perform both an international classic, Tartuffe by Molière, and three domestic classics, one-act-plays by Aleksis Kivi Lea, Night and Day, and Engagement. By contrast, in Tallinn, the Finnish National Theatre chose to perform a contemporary comedy, Unruly Generation by Mika Waltari.

Aleksis Kivis's plays were, from early on, almost a compulsory repertory when a Finnish theatre was visiting abroad. According to Anneli Saro, actors of the Finnish National Theatre had performed Aleksis Kivi's Heath Cobblers when the theatre had visited Narva in 1912. ${ }^{42}$ Since the Swedish Theatre in Helsinki, a Helsinki based theatre performing in Swedish, had visited the Royal Dramatic Theatre with a production of Heath Cobblers in September 1935, choosing the same play was out of the question. ${ }^{43}$ However, in the spring of 1936, the Finnish National Theatre had several Kivi productions to choose from, The Seven Brothers, Lea, Night and Day, and Engagement. Choosing Kivi's play or any other national or international classic, including Molière's Tartuffe, was quite a typical choice for a visiting production. Before the visit, the productions were reviewed in the newspapers and, according to Huugo Jalkanen, the theatre had chosen the best productions for its visiting repertoire. ${ }^{44}$

On 17-19 April 1936, the Royal Dramatic Theatre performed in Helsinki Friedrich von Schiller's Mary Stuart and Jean-Jacques Bernard's The Spared House (Huset vid landsvägen). Mary Stuart was performed twice, on 17 and 19 April. The Spared House, directed by Alf Sjöberg, received an especially

39 The minutes of the meetings of the Royal Dramatic Theatre 27.2.1935 and 2.5.1935. Kungl. Dramatiska teaterns aktiebolag. 1934-1935 års handlingar. Archive of the Royal Dramatic Theatre. 40 The minutes of the meeting of the board of the Royal Dramatic Theatre 5.3.1936. Kungl. Dramatiska teaterns aktiebolag. 1935-1936 års handlingar. Archive of the Royal Dramatic Theatre. 41 Meinander 1999, 134-135.

42 Saro.

43 The Swedish Theatre in Helsinki had visited the Royal Dramatic Theatre on 20-30.9.1935. The planning of this visit had started in February 1935. The minutes of the meetings of Royal Dramatic Theatre 27.2.1935 and 2.5.1935. Archive of the Royal Dramatic Theatre.

44 H. J-n Uusi Suomi 14.4.1936. 
positive response..$^{45}$ Mary Stuart and Tartuffe were both productions whereby the theatres could showcase their quality in staging international classics. Obviously, both theatres, the Finnish National Theatre and the Royal Dramatic Theatre, had cast the productions with the best actors of their ensembles. In my opinion, it was not only the diplomatic correctness of the critics but also the skilled actors of the two theatres that lead to the visits being a success. For example, in the production of Mary Stuart, directed by Olof Molander, the casting of Tora Teje as Elizabeth made Elizabeth the main character of Molander's interpretation. ${ }^{46}$ It is impossible to look at all these visiting performances in one article, therefore I have decided to focus on the most unlikely choice in the visiting performances, Unruly Generation by Mika Waltari.

Unruly Generation premiered at the Finnish National Theatre on 22 January 1937. ${ }^{47}$ The production was directed by a visiting director Wilho IImari who had directed the play's first premiere at the Tampere Theatre, too. Unruly Generation was remarkably popular in the late 1930s, being produced in six different theatres in Finland. IImari also directed a film based on the play for the Finnish Film Industry in $1937 .{ }^{48}$

The production of Waltari's play at the Finnish National Theatre was praised. Waltari was seen to have matured as a writer, which was reflected in a more understanding attitude towards the views of different generations. Wilho IImari's direction showed a stage-driven imagination and a strong artistic vision. The performances of the actors were considered good across the board. Professor Reinhold Varavaara's role was played by Uuno Laakso, who credibly expressed the extremes of the character's behaviour. The role of his spouse was played by Tyyne Haarla and Päivi Horsma. Henny Waljus (Marja), Joel Rinne (Kali), Unto Salminen (Pelle), Sointu Kouvo (Japi), Jorma Nortimo (Husu), and Laura Tudeer (Löpö) portrayed the youth of the play.

The newspaper Uusi Suomi reported that the Finnish National Theatre would visit the Estonia Theatre on 4 May 1937. Also, the author of the Unruly Generation Mika Waltari joined the ensemble. ${ }^{49}$ This performance was sold out. The evening started with the national anthem of Finland, Maamme, played by the Estonia Orchestra. Many members of the Estonian government were in the audience, including Prime Minister Kaarel Eenpalu and Finance Minister Karl Selter. P. J. Hynninen, while the Finnish Minister to Tallinn was also present. ${ }^{50}$ At the end of the presentation, Eino Kalima received a bouquet from the Prime Minister Eenpalu and his spouse and Kalima was also invited to become an

45 Koskimies 1972, 356-357.

46 R. Suomen Sosialidemokraatti 19.4.1936. My argument about the visiting performances is based on archival material from the archives of the Finnish National Theatre, the Royal Dramatic Theatre and the Estonian Theatre and Music Museum and altogether more than 80 articles published in Estonian, Finnish and Swedish newspapers.

47 Koskimies 1972, 366-368.

48 Laine, Santakari, Seitajärvi and Hupaniittu 2019, 157, 162. Information on the productions of Unruly Generation (Ilona).

49 s.n. Uusi Suomi 1.5.1937.

50 K Uusi Suomi 5.5.1937; s.n. Helsingin Sanomat 5.5.1937. 
honorary member of the Estonian Artists' Association. ${ }^{51}$

Finnish newspapers reported the reception, referring to Estonian journals. The reviews highlighted how all the parts were cast with the driving forces of the theatre. ${ }^{52}$ The programme confirms this as Unruly Generation featured the most important actors in the 1930s ensemble. The main differences between Estonian and Finnish theatre were again seen in acting. The Finnish acting was considered more expressive, while the Estonian acting was more sophisticated and intense. According to Helsingin Sanomat, the critic of the Vaba Maa said that Finnish theatre was older than Estonian theatre and thus of a higher standard. The reason for this was found by the reviewer to be good theatre training..$^{53}$ The praise on both sides was a gesture of hospitality and courtesy but also a sign of appreciation. Although both the Finnish National Theatre and the Estonia Theatre visited with their lighter and more entertaining productions, they were performed by the best actors of the two theatres.

\section{Theatre Visits as Cultural Exchange}

The visits of the Finnish National Theatre discussed in this article were part of the cultural diplomacy of the state. The governments supported the visits and high-level politicians participated in these visits in different ways. Based on the public response, the visits were successful in drawing positive publicity towards the theatres and to the cultural relationships between the countries. They were part of the countries' soft power in J. S. Nye's terms. According to Suomen Kuvalehti, "The reciprocal visits of the artists of the National Theatre and the Estonian Theatre are strictly based on the exceptional cultural sympathy and kinship of Finland and Estonia." 54

In 1937, an agreement on cultural cooperation was signed between Estonia, Finland, and Hungary. ${ }^{55}$ The treaty was a unique treaty because it was not terminated during the era Estonia was part of the Soviet Union. Before the outbreak of World War II, the Estonia Theatre still had a chance to visit the Finnish National Theatre on 4 May 1939, with a performance In Püve Farm (Püve talus) by August Kitzberg directed by Ants Lauter. ${ }^{56}$ After World War II, the visits to the Estonia Theatre became difficult and the Finnish National Theatre turned to the west. The first visits in the 1950s took place in Paris in 1955 and in Stockholm in 1956.

51 Kilkot Helsingin Sanomat 6.5.1937.

52 s.n. Suomen Sosialidemokraatti 6.5.1937; s.n. Helsingin Sanomat 6.5.1937.

53 s.n. Helsingin Sanomat 6.5.1937.

54 Raud Suomen Kuvalehti 28.2.1931.

55 Rausmaa 2007, 21.

56 s.n. Uusi Suomi 4.5.1939. 


\section{AUTHOR}

Hanna Korsberg has been Professor of Theatre Research at the University of Helsinki since 2008. Her research interests include the relationship between theatre and politics in Finland, a topic which she has studied in two monographs. She is also the author of several articles discussing theatre history, historiography, and performance. She has been an active member of the International Federation for Theatre Research (IFTR) Historiography Working Group since 2001, an executive committee member in 20072015, and Vice President during 2015-2019. She has served as a member of the advisory boards for Contemporary Theatre Review and Nordic Theatre Studies. She is also a member of the Teachers' Academy at the University of Helsinki.

\section{REFERENCES}

Koskimies, Rafael.1972. Suomen Kansallisteatteri 2. Helsinki: Otava.

Laine, Kimmo, Minna Santakari, Juha Seitajärvi and Outi Hupaniittu. (eds.). 2019. Unelmatehdas Liisankadulla. Suomen Filmiteollisuus OY:n tarina. Suomalaisen Kirjallisuuden Seuran toimituksia 1450. Helsinki: Suomalaisen Kirjallisuuden Seura.

Meinander, Henrik.1999. Tasavallan tiellä. Suomi kansalaissodasta 2000-luvulle. Helsinki: Schildts.

Nye, J. S. 2008. "Public Diplomacy and Soft Power." The ANNALS of the American Academy of Political and Social Science 616 (1), 94-109.

Rausmaa, Heikki. 2007. Tuglaksen tuli palaa. Tuglas-seuran ja suomalais-virolaisten suhteiden historiaa. Helsinki: Suomalaisen Kirjallisuuden Seura.

Reinelt, Janelle. 2008. "First Keyword Lecture." A MAIPR faculty lecture. A manuscript, 4.

Saro, Anneli. "Viron ja Suomen teatterisuhteet toiseen maailmansotaan asti". A manuscript.

Tompkins, Joanne. 2003. "Space and the Geographies of Theatre: Introduction." Modern Drama 46:4, 537-541.

Tormis, Lea. 1978. Eesti teater 1920-1940. Sõnalavastus. Tallinn: Eesti Raamat.

Vertovec Steven. 1991. "Conceiving and Researching Transnationalism." Ethnic and Racial Studies 22: 2, 447-462.

Vesikansa, Jyrki. "Soini, Yrjö." Kansallisbiografia. Studia Biographica 4. Helsinki: Suomalaisen Kirjallisuuden Seura. 1997- (14.8.2019). 
Veski, Kristi. 2014. Eesti teatrikontaktid Soomega aastatel 1906-1939. BA thesis, University of Tartu.

Wilmer, S. E. 2001. "German Romanticism and its Influence on Finnish and Irish Theatre." In Helka Mäkinen, S. E. Wilmer, W. B. Worthen (eds.). Theatre, History and National Identities. Helsinki: Helsinki University Press, 15-69.

\section{Newspapers and magazines}

Esirippu, Esa [pseudonym]. 1931. "Teatterikatsaus." Tuulispää 15.3.1931, 4.

Jalkanen, Huugo. "Estonian näyttelijäin vierailu Kansallisteatterissa." Uusi Suomi 7.3.1931, 8.

J-n, H. [Jalkanen, Huugo]. 1931. "Kiven yksinäytöksiset Kansallisteatterissa." Uusi Suomi 14.4.1936, 8.

K [Kivimaa, Arvi]. 1931. "'Ei tarvita Suomen - Viron siltaa!' 'Suomalaiset ja virolaiset näyttelijät ovat veljiä ilman siltaakin." Uusi Suomi 6.3.1931, 7.

K [Kivimaa, Arvi]. 1931. “Jälkipoimintoja näyttelijävierailusta.” Uusi Suomi 7.3.1931, 8.

K [Kivimaa, Arvi]. 1937. "Kansallisteatterin vierailu Tallinnassa." Uusi Suomi 5.5.1937, 9.

Kilkot [pseudonym]. 1937. "Kansallisteatteri kävi 'valloittamassa' Tallinnan." Helsingin Sanomat 6.5.1937, 10.

Köpi [pseudonym]. 1931. "Taiteilijavierailut." Ajan Sana 26.2.1931, 5.

M-o [pseudonym]. 1931. "Eestiläisvierailu Kansallisessa." Ylioppilaslehti 7.3.1931, 17-18.

Paavolainen, Olavi. 1931. "Virolainen teatterivierailu." Aamu 3-4, 1.3.1931, 32.

Raud, Märt. 1931. "Lauluisa ja Kirjaneitsi. Kreutzwaldin ja Koidulan tarina Estonian näyttämöllä." Suomen Kuvalehti 9/1931 28.2.1931, 410-411.

R., K.-M. [Rydberg, Kaisu-Mirjami]. 1936. "Psykologista realismia Ruotsin päänäyttämöllä. Schiller: Maria Stuart." Suomen Sosialidemokraatti 19.4.1936, 8.

s.n. 1931. "Estonian näyttelijäin toinen vierailu Kansallisteatterissa." Uusi Suomi 5.3.1931, 6.

s.n. 1931. "Illanvietto vierailijoille eilen." Helsingin Sanomat 4.3.1931, 7.

s.n. 1931. "Tallinna juhlii suomalaisia näyttelijävieraita." Uusi Suomi 4.3.1931, 6.

s.n. 1931. "Tallinnalaista elävän sanan taidetta." Helsingin Sanomat 1.3.1931, 16.

s.n. 1931. "Tallinnan Estonia Teatterin ja Kansallisteatterin vuorovierailu." Helsingin Sanomat 2.3.1931, 4 . 
s.n. 1931. "Teatterivierailu Estoniassa." Helsingin Sanomat 5.3.1931, 7.

s.n. 1931. "Veljesmaan näyttelijät vierailevat Helsingissä tiistaina ja keskiviikkona." Uusi Suomi 1.3.1931, 9 .

s.n. 1931. "Virolainen vierailu Kansallisteatterissa." Suomen Sosialidemokraatti 4.3.1931, 6.

s.n. 1937. "Kansallisteatteri saavuttanut menestystä Tallinnassa." Suomen Sosialidemokraatti 6.5.1937, 4 .

s.n. 1937. "Kansallisteatteri vierailulle Viroon." Uusi Suomi 1.5.1937, 17.

s.n. 1937. "Kansallisteatterin näyttelijöillä suuri menestys Tallinnassa." Helsingin Sanomat 5.5.1937, 8.

s.n. 1937. "Kansallisteatterin näyttelijäin esitykset Tallinnassa saavat Viron lehdistön hyvän mainesanan." Helsingin Sanomat 6.5.1937, 10.

s.n. 1939. "Estonia-teatterin vierailu." Uusi Suomi 4.5.1939, 9.

Soini, Yrjö. 1930. "Pessimismistä optimismiin." Aitta 1.1.1930, 12-13.

Viljanen, Lauri. 1931. "Virolainen teatterivierailu." Helsingin Sanomat 5.3.1931, 7.

V.H. [Välisalmi, Heikki]. 1931."Toinen virolaisten näyttelijäin vierailu." Suomen Sosialidemokraatti 5.3.1931, 5 .

\section{Archives and Databases}

Archive of the Finnish National Theatre, Helsinki. The minutes of the Finnish National Board meeting 13.1.1931. The program of Journey's End.

Archive of the Royal Dramatic Theatre, Stockholm. Kungl. Dramatiska teaterns aktiebolag. 1934-1935 års handlingar. The minutes of the meetings of Royal Dramatic Theatre 27.2.1935 and 2.5.1935. Kungl. Dramatiska teaterns aktiebolag. 1935-1936 års handlingar. The minutes of the meeting of the board of the Royal Dramatic Theatre 5.3.1936.

Archive of Eesti Teatri- ja Muusikamuuseum, Tallinn. The program of Patuoinas Estonia Teater.

Literary and cultural history resources of the Finnish Literature Society, Helsinki. The Archive of Eino Kalima. A letter from Ants Lauter to Eino Kalima 1.6.1931. 533:51:1.

Ilona, Finnish theatre database, http://ilona.tinfo.fi/. 